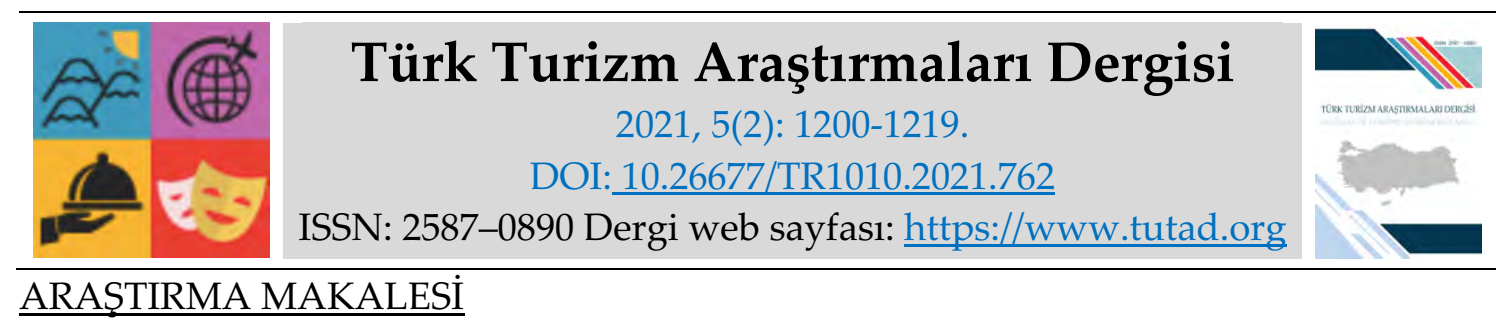

\title{
Rehberli Turlarda Algılanan Değer, Akış Deneyimi ve Davranışsal Niyet İlişkisi: Çanakkale Savaşları Gelibolu Tarihi Alanı Örneği*
}

Onur AKGÜL, Doktora Öğrencisi, Çanakkale Onsekiz Mart Üniversitesi, Lisansüstü Eğitim Enstitüsü, Çanakkale, e-posta: onurakgul@yahoo.com

ORCID: https://orcid.org/0000-0002-5229-2557

Prof. Dr. Özlem KÖROĞLU, Balıkesir Üniversitesi, Turizm Fakültesi, Balıkesir, e-posta: okoroglu@balikesir.edu.tr

ORCID: https://orcid.org/0000-0002-3974-6120

Öz

Turizm sektörünün çok yönlü mesleklerinden biri olan turist rehberliğinin temelinde insan ilişkileri yer almaktadır. Turist rehberleri, ziyaret edilen bölgeyi sadece tanıtmakla kalmamakta, sunduğu hizmetle misafirlerinin tur deneyimine dair birtakım duygular hissetmelerini sağlamaktadır. Nitekim rehberli turların tercih edilmesindeki önemli etkenler arasında keyifli zaman geçirme imkânının olduğu bilinmektedir. Bu sayede insanlar aldığ1 hizmete dair memnuniyet ve mutluluk duymaktadırlar. Turizm de insanların mutluluk arayışı için başlattığı sosyal ve boş zaman olgusu olarak nitelendirildiği için pozitif psikoloji ile yakından ilgilidir. Bu araştırmada, rehberli turlarda algılanan değer, akış deneyimi ve davranışsal niyet ilişkisinin belirlenmesi amaçlanmıştır. Bu bağlamda Çanakkale Savaşları Gelibolu Tarihi Alanı'nı turist rehberi eşliğinde ziyaret eden 396 yerli turistten anket yoluyla veriler toplanmıştır. Araştırma sonucunda, turdaki misafirlerin algıladıkları değerin, akış deneyimlerinin ve davranışsal niyetlerinin birbirini etkilediği tespit edilmiştir. Misafirlerin yaşadıkları deneyime dair algıladıkları değerlerle akış deneyimlerinin şekillendiği ve mutlu bir deneyim neticesinde bu deneyime dair olumlu davranışsal niyetler sergiledikleri gözlemlenmiştir.

* Makale, Onur AKGÜL'ün “Rehberli Turlarda Algılanan Değer, Akış Deneyimi ve Davranışsal Niyet İlişkisi: Çanakkale Savaşları Gelibolu Tarihi Alanı Örneği" isimli yüksek lisans tezinden türetilmiştir.

Anahtar Kelimeler: Turist Rehberi, Algılanan Değer, Akış Deneyimi, Davranışsal Niyet, Gelibolu. Makale Gönderme Tarihi: 10.01.2021

Makale Kabul Tarihi: 04.06.2021

Önerilen Atıf:

Akgül, O. ve Köroğlu, Ö. (2021). Rehberli Turlarda Algılanan Değer, Akış Deneyimi ve Davranışsal Niyet İlişkisi: Çanakkale Savaşları Gelibolu Tarihi Alanı Örneği, Türk Turizm Araştırmaları Dergisi, 5(2): 1200-1219.

(C) 2021 Türk Turizm Araştırmaları Dergisi. 


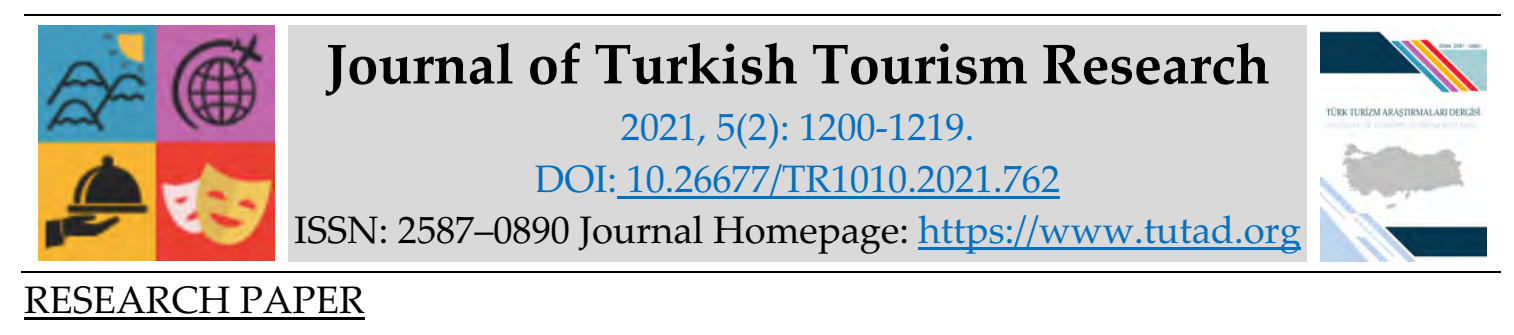

\title{
The Relationship Between Perceived Value, Flow Experience and Behavioral Intention in Guided Tours: The Case of Gallipoli Historic Site
}

Onur AKGÜL, Ph.D. Student, Çanakkale Onsekiz Mart University University, Graduate Education Institute, Çanakkale, e-mail: onurakgul@yahoo.com

ORCID: https://orcid.org/0000-0002-5229-2557

Prof. Dr. Özlem KÖROĞLU, Balıkesir University, Faculty of Tourism, Balıkesir, e-mail: okoroglu@balikesir.edu.tr

ORCID: https://orcid.org/0000-0002-3974-6120

\begin{abstract}
Tourist guidance is one of the multi-faceted professions of the sector and it is based on human relations. The tour guides not only introduce the visited region, but also provide their guests with some feelings about the tour experience with the service they provide. As a matter of fact, it is known that the opportunity to have a pleasant time is among the important factors in the preference of guided tours. In this way, people are satisfied and feel happy about the service they receive. Tourism is also closely related to positive psychology as it is defined as a social and leisurely phenomenon that people initiated in search of happiness. The aim of this study was to determine the relationship between perceived value, flow experience and behavioral intention in guided tours. In this context, data were collected from 396 local tourists who visited The Gallipoli Historic Site accompanied with a tour guide. In line with the analysis of the data obtained from the participants, it was determined that the perceived value, flow experience and behavioral intentions of the guests in the guided tour affected one another. It was observed that the flow experience of the guests was shaped by the values they perceived regarding their experience and that they exhibited positive behavioral intentions regarding this experience as a result of a happy experience.
\end{abstract}

Keywords: Tourist Guide, Perceived Value, Flow Experience, Behavioral Intention, Gallipoli.

Received: 10.01 .2021

Accepted: 04.06.2021

Suggested Citation:

Akgül, O. and Köroğlu, Ö. (2021). The Relationship Between Perceived Value, Flow Experience and Behavioral Intention in Guided Tours: The Case of Gallipoli Historic Site, Journal of Turkish Tourism Research, 5(2): 1200-1219.

(c) 2021 Türk Turizm Araştırmaları Dergisi. 


\section{Gíriş}

Turist rehberliği hizmeti, turizm sektörünün başarıya ulaşmasına yardımcı olan, hizmet sektörünün çok yönlü ve profesyonel mesleklerinden biridir ve temeli insan ilişkilerine dayanmaktadır (Yenipınar, 2019). Turist rehberleri, seyahat acentalarının organize ettiği turları gerçekleştirerek, ziyaret edilen bölgenin tarihi, kültürel, doğal ve sosyal değerlerini turistlere tanitan kişilerdir. Rehberle gerçekleştirilen turlarda turistler, anlatılan coğrafi, gastronomik ve mitolojik hikayeleri zihinlerinde canlandırarak destinasyonun bir resmini oluşturabilmektedir (Altıntaş vd., 2017: 268). Çetinkaya ve Öter'in (2016: 50) çalışmasında, rehberli turların tercih nedenleri arasında gezilen bölgeyle ilgili daha detaylı ve özel bilgiler edinerek daha keyifli zaman geçirme imkânı olduğu ifade edilmektedir. Bu etkenler de turistlerin aldığı hizmetten memnuniyet duymasını sağlamaktadır.

Mutluluğu anlamaya çalışan pozitif psikoloji insan memnuniyeti ile yakından ilgilidir (Filep, 2008: 91). Pozitif psikoloji, olumlu duygular, olumlu karakter özellikleri ve bunu sağlayan kurumların değerlendirilmesine yönelik genel bir terimdir (Seligman vd., 2005: 410). Turizm alanında ise bugüne kadar az sayıda pozitif psikoloji analizi yapılmıştır (Filep, 2007). Aralarındaki ilişkiye bakıldığında pozitif psikoloji ve turizm, insanın temel arzularının yerine getirilmesine birlikte katkıda bulunmaktadır (Filep, 2012: 45).

Bir turun fonksiyonel değer unsurlarının yanı sıra, sosyal-psikolojik boyutlarının da güçlü bir şekilde ortaya çıktığı görülmektedir (Williams ve Soutar, 2000: 1419). Rehberli turlara katılan turistler sadece yeni yerler keşfetmek ve yeni bilgiler öğrenmekle kalmamakta, aynı zamanda yaşadıkları bu tecrübeyle ilgili birtakım değerler edinmekte ve duygular hissetmektedirler.

Tarihi ve manevi değerler açısından büyük bir önemi olan Çanakkale Savaşları Gelibolu Tarihi Alanı'na gerçekleştirilen turlara katılan turistler hem turist rehberinden hem de turdaki diğer ürünlerden aldıkları hizmete yönelik değerlendirmeler yapmakta ve yaptıkları eyleme odaklanarak bütünsel bir duygu haline girmektedirler. Bunların da etkisiyle ziyaretçiler, aldıkları ürün/hizmete dair izlenimler edinmektedirler. Turizm ve pazarlama literatürü ele alındığında, tüketicilerin satın aldığı ürün veya hizmete yönelik edindikleri ekonomik faydalar, hizmet faydaları, teknik ve sosyal faydalar algılanan değer (Bekar, 2012: 5); satın alınan hizmet içinde yer alan faaliyete odaklanarak hissedilen çeşitli duygular da akış deneyimi olarak tanımlanmaktadır. Davranışsal niyet ise bir ürün veya hizmetin satın alınmasından sonra yaşanan memnuniyet veya memnuniyetsizlik sürecinin nihai sonucudur ve potansiyel bir turistin gelecekte destinasyona yönelik seyahatinin öngörülmesi (Anderson vd., 1994: 53) olarak ifade edilmektedir.

Yapılan literatür taramasında, turist rehberi eşliğinde gerçekleştirilen turların, pozitif psikolojiye olan etkisine dair akademik bir çalışmaya rastlanılmamıştır. Bu bağlamda, Çanakkale Savaşları Gelibolu Tarihi Alanı'na yönelik gerçekleştirilen rehberli turlarda algılanan değer, akış deneyimi ve davranışsal niyet arasındaki ilişkinin daha önce tespit edilmemesi, bu araştırmanın problemini oluşturmaktadır. Bu nedenle çalışmada, söz konusu problemden yola çıkarak bu ilişkinin tespit edilmesi amaçlanmaktadır.

\section{KAVRAMSAL ÇERÇEVE}

\section{Algılanan Değer}

Algılanan değer, bir ürün veya hizmetin karşılığı olarak alınanların karşısında verilenlerin algılanmasına dayanan, ilgili ürün veya hizmete dair genel fayda değerlendirmesi olarak ifade edilmektedir (Zeithaml, 1988: 14). Bir başka çalışmada da bu kavram, satın alma öncesi de dâhil 
olarak satın almaya yönelik işlemlerin bütün basamaklarında, satın alma sonrasında ve kullanım sonrasındaki değerlendirme ile hissedilen tatmin olarak ifade edilmektedir (Sweeney ve Soutar, 2001: 206). Algılanan değer, yalnızca ön satın alma aşamasında etkili olmakla kalmayıp, satın alma sonrasında da müşteri memnuniyetini ve öneride bulunma niyetini de etkilemektedir (Dodds vd., 1991; Parasuraman ve Grewal, 2000).

Algılanan değerin farklı boyutları vardır. Öne çıkan boyutlar; duygusal değer, fonksiyonel değer, sosyal değer, epistemik değer, durumsal değer, ekonomik değer, psikolojik değer ve kalite değeridir. Bu boyutlar, müşteri davranışında birer etkendir. Fakat boyutlardan hangisinin daha çok etkiye sahip olduğu, birden fazla etkene göre değişiklik gösterebilmektedir. Bununla birlikte ürünü/hizmeti alıp almama üzerine karar verme aşamasında farklı değer boyutları önem taşıyabileceği gibi, satın alınma aşamasında olan ürünün/hizmetin türü de önem taşımaktadır (Sheth vd., 1991).

\section{Akış Deneyimi}

Akış deneyimi, kişinin yapmakta olduğu eyleme dikkatini toplayarak yoğun bir şekilde odaklanması ve o esnada yaptığı eylemin dışındaki her şeyin önemini kaybederek kişinin kendini soyutlaması olarak tanımlanmaktadır (Csikszentmihalyi, 1990: 4). Başka bir ifadeyle akış deneyimi, bireyin herhangi bir eylem/etkinlik icrasında zorluk ve beceri dengesinin yüksek olması, eylemin kontrol altına alındığını hissetmesi ve geri değerlendirme alması, dikkatini yaptığ 1 işe odaklayarak özbilinç kaybının yaşanması ve işin sonunda haz almasına yönelik bir bilinç hali şeklinde tanımlanmaktadır (Csikszentmihalyi, 2005: 60). Akış deneyimi, "optimum" bir deneyimdir. Optimum deneyim, bireyin uzun süredir beslediği ve yaşaminda bir dönüm noktası haline gelebilen mutluluk ve derin bir haz duygusu olarak ifade edilmektedir (Csikszentmihalyi, 1990).

Akış deneyimi dokuz alt boyuttan meydana gelmektedir. Bu boyutlar; "açık hedefler", "eylem ve farkındalık birleşimi", "geribildirim", "konsantrasyon", "kontrol", "ototelik deneyim", "özbilinç kaybı", "zamanın dönüşümü" ve "zorluk ve beceri dengesi" olarak ifade edilmektedir. Akış deneyimi yaşayan bireylerde, bu boyutlardan en az biri gözlemlenebilmektedir (Csikszentmihalyi, 1990: $45)$.

Psikoloji alanına giren akış deneyimi, son yirmi yıl içinde ilerleme gösterdiği literatürde farklı araştırmacıların sürdürdüğü çeşitli çalışmalarda ele alınmıştır (Yeşiltaş ve Ekici, 2017: 2). Turizm literatüründe akış deneyiminin araştırıldığ Filep'in (2008: 104) çalı̧̧masında, akış deneyiminin turist memnuniyeti ile ilişkisi değerlendirilmiş ve yurt dışı ziyareti tecrübesi edinen yirmi öğrenci üzerinde bir yıl süre zarfında derinlemesine görüşme tekniği ile mülakat yapılmıştır. Araştırma sonucunda, akış deneyiminin turist memnuniyeti ile doğrudan ilişkili olduğu sonucuna varılmıştır. Söz konusu memnuniyetin oluşmasında, turist rehberlerinin bilgi, beceri ve kabiliyetleri çok önemlidir. Turist rehberleri, bir destinasyon ve kültür elçisi olarak, turistlerin aldıkları tur hizmetinden duydukları memnuniyet düzeylerine ve ülke imajına doğrudan etki etmektedir (Köroğlu vd., 2018: 344). Turist rehberlerinin literatürde tanımlanan rollerinden "sosyal rol" kapsamında da turistlerin moral ve motivasyonlarının yükseltilmesi, turist rehberlerinin sorumlulukları arasında yer almaktadır (Asmadili, 2015: 34). Bu bağlamda turist rehberlerinin, akış deneyiminin yaşanmasına önemli bir etken olabileceği ifade edilebilmektedir. 


\section{Davranışsal Niyet}

Pazarlama literatüründe davranışsal niyet, müşterilerin belirli bir ürün veya hizmet işletmesi ile ilişkilerini sağlamlaştırdığının ve bu ilişkinin devam edeceğinin bir göstergesi olarak ifade edilmektedir (Zeithaml vd., 1996: 33). Davranışsal niyet, bir müşterinin bir ürün veya hizmetten tekrar faydalanıp faydalanmayacağının habercisidir (Baker ve Crompton, 2000).

Turizm sektörü ele alındığında davranışsal niyetler, potansiyel bir turistin gelecekte destinasyona seyahatinin öngörülmesi olarak tanımlanmaktadır (Fishbein ve Ajzen, 1975: 292 'den akt. Dalkılıç, 2012). Literatürde, davranışsal niyetin sıklıkla memnuniyet, kalite veya duygular üzerine çalışıldığı görülmektedir (Çetinkaya, 2016). Özellikle kalite ve memnuniyetin davranışsal niyetler üzerinde önemli derecede etkisi olduğu belirtilmektedir (Baker ve Crompton, 2000: 799). Turist rehberlerinin de memnuniyet düzeyine önemli etkileri vardır. Moscardo (2003: 116) tarafından yapılan çalışmada, turist rehberlerinin yorumlayıcı rolünün, turist memnuniyetinin ve turizm hareketliliğinin artmasına imkân verdiği belirtilmektedir.

Davranışsal niyetin, incelendiği alana göre çeşitli alt boyutları vardır. Turistler açısından ele alındığında, davranışsal niyetin ilk boyutu olarak "tekrar ziyaret niyeti" ortaya çıkmaktadır. Tekrar ziyaret niyeti, turistin ilgili destinasyona bağlılığının anlaşılmasında önemli bir ölçü olarak görülmektedir (Chen ve Gürsoy, 2001). Turistlerin davranışsal niyetlerinin ölçülmesinde kullanılan bir diğer boyut ise "tavsiye niyeti" dir. Tavsiye niyeti, memnuniyetle paraleldir. Yani memnuniyetin yüksek olduğu bir durumda, yakın çevreye yönelik öneriler de o şekilde güçlü olmaktadır (Bigne vd., 2001). Başka insanlardan alınan tavsiyeler, seyahat niyeti olan insanlar için en güvenilen ve başvurulan bir bilgi kaynağıdır (Yoon ve Uysal, 2005: 46). Bir sonraki boyut "olumlu yorumlar" olarak ortaya çıkmaktadır. Turistlerin, yaşadıkları deneyimle alakalı çevresindeki insanlara olumlu yorumlarda bulunması, o turistlerin destinasyona olan bağlılığının da yüksek olduğunun bir göstergesidir (Liu vd., 2012).

Turizm alanında algılanan değer, akış deneyimi ve davranışsal niyet değişkenlerinin ikili olarak ilişkilendirildiği farklı çalışmalar literatürde yer almaktadır. Akkılıç ve Varol'un (2015) çalışmasında, Edremit Körfezi bölgesine gelen yerli turistlerin algılanan değerlerinin davranışsal niyetler üzerine etkisi incelenmiştir. İlban vd., (2016) tarafından yapılan çalışmada, Balıkesir/Edremit ilçesindeki termal oteller kapsamında algılanan hizmet kalitesi, memnuniyet ve davranışsal niyetler arasındaki ilişkiler incelenmiştir. Kim ve Thapa (2018) tarafından yapılan çalışmada, Güney Kore'deki Jeju Adası'nı kapsayan bir ekoturizm turuna katılan turistlerin algılanan değerlerinin, akış deneyimi ve memnuniyet üzerindeki etkileri ölçülmüştür. Usullu (2019), turist rehberlerine yönelik algılanan kalite değerinin davranışsal niyetlere etkisini incelemiştir. Algılanan değer, akış deneyimi ve davranışsal niyet değişkenlerinin bir arada kullanıldığı çalışma, yürüyüş deneyimine ilişkin akış durumunun algılanan değer ve davranışsal niyet üzerindeki etkisini inceleyen Çeşmeci'nin (2018) doktora tezidir. Bu bağlamda, turizm literatüründe algılanan değer, akış deneyimi ve davranışsal niyet ilişkisinin incelendiği çok az sayıda akademik çalışmaya rastlandığı için bu çalışmanın turizm literatürüne katkı sağlayacağ öngörülmektedir.

\section{YÖNTEM}

\section{Araştırmanın Modeli ve Hipotezleri}

Araştırmanın amacı doğrultusunda algılanan değer, akış deneyimi ve davranışsal niyetin ilişkilendirilerek ele alındığı çalışmalardan yola çıkılarak geliştirilen hipotezler şu şekildedir:

- H1: Rehberli turlarda algılanan değerin, akış deneyimine etkisi vardır. 
- H11: Rehberli turlarda algılanan duygusal değerin, akış deneyimine etkisi vardır.

- H12: Rehberli turlarda algılanan sosyal değerin, akış deneyimine etkisi vardır.

- H13: Rehberli turlarda algılanan kalite değerinin, akış deneyimine etkisi vardır.

- H14: Rehberli turlarda algılanan fiyat değerinin, akış deneyimine etkisi vardır.

- H2: Rehberli turlarda algılanan değerin, davranışsal niyete etkisi vardır.

- H21: Rehberli turlarda algılanan duygusal değerin, davranışsal niyete etkisi vardır.

- H22: Rehberli turlarda algılanan sosyal değerin, davranışsal niyete etkisi vardır.

- H23: Rehberli turlarda algılanan kalite değerinin, davranışsal niyete etkisi vardır.

- H24: Rehberli turlarda algılanan fiyat değerinin, davranışsal niyete etkisi vardır.

- H3: Rehberli turlarda akış deneyiminin, davranışsal niyete etkisi vardır.

Söz konusu hipotezlerden yola çıkarak oluşturulan araştırma modeline Şekil 1'de yer yerilmektedir.

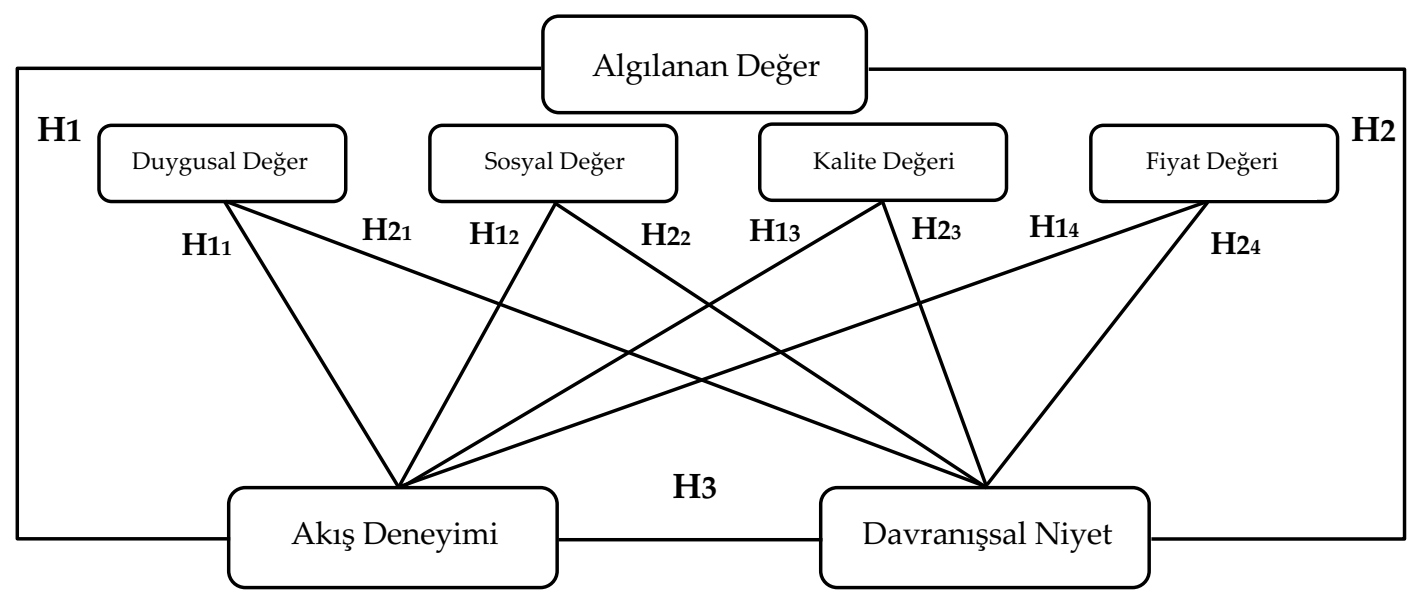

Şekil 1. Araştırma Modeli

\section{Evren ve Örneklem}

$\mathrm{Bu}$ araştırmanın evrenini Çanakkale Savaşları Gelibolu Tarihi Alanı'nı rehberli tur ile ziyaret eden yerli turistler oluşturmaktadır. Gelibolu Tarihi Alanı'nda bir giriş kontrolü yer almadığı için alanı ziyaret eden kişi sayısına dair Çanakkale Savaşları Gelibolu Tarihi Alan Başkanlığı (ÇATAB) tarafından bir istatistik tutulamıyor olsa da Tarihi Alan sınırları içinde yer alan Çanakkale Destanı Tanıtım Merkezi'nin ziyaretçi sayısına dair istatistik bulunmaktadır. Çanakkale Savaşları Gelibolu Tarihi Alan Başkanlığı'nın 2019 yılına ait faaliyet raporunda yer alan verilerde Çanakkale Destanı Tanıtım Merkezi'nin, faaliyete geçtiği 2012 yılından 2019 yılına kadar olan süreçte toplamda 1.972 .575 kişi tarafından ziyaret edildiği görülmektedir (https://catab.ktb.gov.tr). Bu kapsamda Çanakkale Savaşları Gelibolu Tarihi Alanı'nı rehberli tur ile ziyaret eden kişilerin oluşturduğu evren büyüklügünün 2 milyon civarında olduğu söylenebilir. Örnek kütleden elde edilen verilerle evren hakkında genellemeler yapmak için gerekli olan kabul edilebilir örneklem büyüklükleri baz alındığında, evren büyüklüğü 2 milyon civarında olan bir araştırma için örneklem büyüklügü 387 olarak kabul görmektedir (Coşkun vd., 2015: 137).

Bu çalışmada, olasılığa dayalı olmayan örnekleme yöntemlerinden "kolayda örnekleme" yöntemi kullanılmıştır. Anket toplama sürecinde toplam 402 ziyaretçiden veri elde edilmiştir. Ancak 6 anket, eksik ve tutarsız veri içerdiğinden analize tabi tutulmamıştır. Sonuç olarak 
çalışmaya dâhil edilen örneklem olarak 396 adet anket formunun verilerinden değerlendirme yapılmıştır.

\section{Veri Toplama Aracı ve Süreci}

Araştırmaya dâhil edilecek verilerin toplanması için birincil kaynak kullanımı gerekliliğinden dolayı anket yönteminden yararlanılmıştır. İki bölümden oluşan anketin birinci bölümünde, Çanakkale Savaşları Gelibolu Tarihi Alanı'nı turist rehberi eşliğinde ziyaret eden turistlerin algılanan değer, akış deneyimi ve davranışsal niyetlerini ölçmeye yönelik toplam 28 ifade yer almaktadır. İlk 16 ifade, katılımcların algılanan değerlerini belirlemeye yönelik olan, Sweeney ve Soutar'ın (2001) geliştirdiği PERVAL ölçeğinin Tangpattanakit (2017) tarafından 4 alt boyutta; duygusal değer, sosyal değer, parasal değer ve kalite değeri olarak ölçmeye uyarladığ1 çalışmadan baz alınarak oluşturulmuştur. Sonraki 9 ifade, Jackson vd., (2008) tarafından oluşturularak güvenirlik ve geçerliği sağlanan 9 ifadeye indirgenmiş akış deneyimi ölçeğinden baz alınmıştır ve her ifade, akış deneyiminin birer boyutunu ölçmektedir. Bunlar sırasıyla: becerizorluk dengesi, eylem-farkındalık birleşimi, açık hedefler, geribildirim, göreve odaklanma, kontrol hissi, zamanın dönüşümü, özbilinç kaybı ve ototelik deneyimdir. Davranışsal niyet için de Lee, Graefe ve Burns (2004) tarafından oluşturulan 3 ifadeli ölçek kullanılmıştır ve bu bağlamda davranışsal niyetin tekrar ziyaret niyeti, tavsiye niyeti ve olumlu yorum niyeti boyutları birer ifadeyle ölçülmüştür.

Araştırmada yararlanılan ölçekler doğrultusunda beşli Likert tipi kullanılan ankette yer alan ifadeleri, katılımciların "1. Kesinlikle Katılmıyorum, 2. Katılmıyorum, 3. Kararsızım, 4. Katılıyorum, 5. Kesinlikle Katılıyorum" seçeneklerinden birini işaretleyerek yanıtlamaları istenmiştir. Anketin ikinci bölümünde de katılımcıların cinsiyet, yaş, medeni durum, öğrenim durumu ve meslek bilgilerini içeren sosyo-demografik sorular yöneltilmiş ve geçmişte Çanakkale Savaşları Gelibolu Tarihi Alanı'nı turist rehberiyle veya rehbersiz ziyaret etme durumları, ziyareti gerçekleştirmeye etki eden faktör ve geçmişte rehberli olan herhangi bir tura katılıp katılmadıkları sorulmuştur.

Oluşturulan anket formu, 2020 yılı Şubat ayından itibaren tarihi alanı rehberle ziyaret eden yerli turistlere, turun sona ermesinin ardından dağıtılarak veri toplanmıştır. Tarihi Alanı daha önce en az bir defa turist rehberi ile ziyaret etmiş olan yerli turistlere ise telefon ve sosyal medya aracılığıyla ulaşılarak çevrimiçi anket yoluyla veri elde edilmiştir. Veri toplama süreci Haziran ayında tamamlanmıştır. Hem basılı hem çevrimiçi ortamdan oluşturulan anket formlarında, anketin sahipleri, kullanım alanı, amacı ve kapsamı hakkında bilgilere yer verilerek, anketin amacı dışında kullanılmayacağına ve formda yer alan cevaplarla diğer kişisel bilgilerin kesinlikle gizli tutulacağına yönelik açıklamalar yapılmıştır.

\section{Verilerin Analizi}

Çalışmaya dâhil olan katılımcıların anket üzerinden verdikleri cevaplardan elde edilen veriler, sosyal bilimlerde kullanılmak üzere geliştirilen bir istatistik programıyla analiz edilmiştir. Daha sonra oluşturulan veri dizisi frekans analizinden geçirilerek değerlendirmeye alınmıştır. 


\section{Araştırmanın Geçerliği ve Güvenirliği}

Araştırmanın amacı doğrultusunda oluşturulan anket formunda yer verilen algılanan değer, akış deneyimi ve davranışsal niyet ölçeklerinin güvenirliği Cronbach's Alpha değeri hesaplanarak sağlanmıştır. Cronbach's Alpha $(\alpha)$ katsayısı, ölçekte bulunan sonuçların varyanslarının toplanarak ölçeğin genel varyansına oranlanması ile elde edilmektedir. 0-1 arasında değer alabilen katsayının 0,70 ve üzerinde olması, ölçeğin kabul edilebilir derecede güvenilir olduğunu ifade etmektedir (Güriş ve Astar, 2015: 283).

14 ifadeden oluşan algılanan değer ölçeğinin güvenilirlik katsayısı 0,908; 9 ifadeli akış deneyimi ölçeğinin güvenilirlik katsayısı 0,793 ve 3 ifadeli davranışsal niyet ölçeğinin güvenilirlik katsayısı 0,789 olarak görülmektedir. Bu veriler doğrultusunda 0,70 üzerinde katsayısı olan 3 ölçeğin de güvenilir olduğu ifade edilebilmektedir.

\section{BULGULAR}

\section{Örneklem Grubunun Demografik Özelliklerine İlişkin Bulgular}

Araştırmaya dâhil olan katılımcıların demografik özelliklerine yönelik frekans analizinin bulgularına göre, 396 katılımcının çoğunluğunun kadın olduğu gözlemlenmektedir. Kadın katılımcıların oranı \%53,3, erkek katılımcıların oranı da $\% 46,7$ olarak görülmektedir. Katılımcların yaşlarına ilişkin bulgulara bakıldığında 21-30 yaş arası bireylerin \%51 oranıyla çoğunluğu oluşturduğu görülmektedir. Diğer yaş gruplarında ise 31-40 yaş arası bireylerin oranı $\% 17,9,20$ yaş ve altı bireylerin oranı $\% 16,4,41-50$ yaş arası bireylerin oranı $\% 7,6$ ve 51 yaş ve üstü bireylerin oranı $\% 7,1$ olarak ortaya çıkmıştır. Katılımcıların medeni durumlarına ilişkin bulgulara bakıldığında \%60,4 oranla bekâr katılımcının, \%39,6 oranla da evli katılımcının araştırmaya dâhil olduğu gözlemlenmiştir. Katılımcıların öğrenim durumlarına bakıldığında \%51,5 oranında katılımcının lisans düzeyinde, $\% 17,4$ oranında katılımcının önlisans düzeyinde, $\% 16,2$ oranında katılımcının lise düzeyinde, $\% 9,6$ oranında katılımcının yüksek lisans düzeyinde, $\% 3$ oranında katılımcının ilköğretim düzeyinde ve $\% 2,3$ oranında katılımcının da doktora düzeyinde öğrenim aldığı görülmektedir. Katılımcıların mesleklerine dair bulgulara bakıldığında ise \%49,7'sinin öğrenci, \%19,4'ünün özel sektör çalışanı, \%9,3'ünün memur, \%9,3'ünün serbest meslek çalışanı, $\% 5,1$ 'inin ev hanımı, \%3,8'inin emekli ve \%1,8'inin işçi olduğu görülmektedir. Diğer meslek grubuna da oyuncu, sporcu ve iş sahibi olmayan bireyler dâhil olmaktadır.

Verilerin devamında, katılımcıların \%52,5'inin geçmişte Çanakkale Savaşları Gelibolu Tarihi Alanı'nı ziyaret ettiği, \%47,5'inin de daha önce bu alanı ziyaret etmediği sonucu ortaya çıkmıştır. Geçmişte Çanakkale Savaşları Gelibolu Tarihi Alanı'nı ziyaret eden 208 katılımcıdan \%73,1'inin turist rehberi eşliğinde bu alanı ziyaret ettiği, \%26,9'unun ise turist rehberi olmadan bu alanı ziyaret ettiği görülmektedir.

Katılımcıların Çanakkale Savaşları Gelibolu Tarihi Alanı'nı ziyaretlerine neden olan faktöre ilişkin bulgular incelendiğinde \%31,3'ünün "Arkadaş/akraba tavsiyesi", \%19,7'sinin "Turist rehberi", \%15,2'sinin "Daha önceki tur deneyimi", \%7,3'ünün "Seyahat acentası", \%4,5'inin ise "Reklam" etkeniyle ziyarette bulundukları görülmektedir. Ayrıca \%22 oranında "Diğer" cevabı olduğu için verilen yanıtlar kendi içinde gruplandırılarak 87 katılımcıdan \%50,6'sının merak, $\% 20,7^{\prime}$ sinin iş/okul gezisi, \%16,1'inin eğitim gezisi, \%6,9'unun kişisel gelişim ve $\% 5,7^{\prime}$ sinin ise tarihe saygı etkenleri nedeniyle bölgeyi ziyaret ettiği ortaya çıkmıştır. Katılımcıların, Tarihi Alanı rehberli tur ile ziyaretleri öncesinde herhangi bir rehberli tura katılıp katılmadıklarına dair yöneltilen sorunun bulguları incelendiğinde $\% 76$ 'sının geçmişte Tarihi Alanı ziyaret etmeden önce başka bir rehberli tura katılım gösterdiği, \%24'ünün de katılmadığı ortaya çıkmıştır. 


\section{Algılanan Değer Ölçeğinin Faktör Analizine İlişkin Bulgular}

Araştırma dâhilindeki anket formunda yer alan algılanan değeri belirlemeye yönelik kullanılan PERVAL algılanan değer ölçeğinin faktör analizi sonuçlarına Tablo 1'de yer verilmektedir.

Tablo 1. Algılanan Değer Ölçeğine Yönelik Faktör Analizi Bulguları

\begin{tabular}{|c|c|c|c|}
\hline & Faktör Yükü & $\begin{array}{c}\text { Öz } \\
\text { Değer }\end{array}$ & $\begin{array}{c}\text { Açıklanan } \\
\text { Varyans }\end{array}$ \\
\hline \multicolumn{4}{|l|}{ Kalite } \\
\hline Turist rehberinin hizmetinden memnun kaldım. & 0,843 & \multirow{5}{*}{3,761} & \multirow{5}{*}{$\% 26,866$} \\
\hline Turist rehberinin bilgisi yeterliydi. & 0,837 & & \\
\hline Tur hizmetleri (rehber, araç, kaptan) kaliteliydi. & 0,774 & & \\
\hline Turist rehberinin hizmeti, ödediğim fiyata değdi. & 0,757 & & \\
\hline Tur programının içeriği yeterliydi. & 0,706 & & \\
\hline \multicolumn{4}{|l|}{ Duygusal } \\
\hline $\begin{array}{l}\text { Gelibolu Tarihi Alanı'nı ziyaret ettiğim için iyi } \\
\text { hissediyorum. }\end{array}$ & 0,839 & \multirow{4}{*}{2,748} & \multirow{4}{*}{$\% 19,626$} \\
\hline Keyifli bir tur oldu. & 0,752 & & \\
\hline $\begin{array}{l}\text { Gelibolu Tarihi Alanı'nı turist rehberi eşliğinde gezmek } \\
\text { beni mutlu etti. }\end{array}$ & 0,742 & & \\
\hline Tura katıldığım için pişman değilim. & 0,688 & & \\
\hline \multicolumn{4}{|l|}{ Sosyal } \\
\hline Tura katıldığım için çevremden olumlu yorumlar aldım. & 0,815 & \multirow{3}{*}{2,133} & \multirow{3}{*}{$\% 15,235$} \\
\hline $\begin{array}{l}\text { Gelibolu Tarihi Alanı'nı ziyaret etmemi çevremdeki } \\
\text { insanlar onayladı. }\end{array}$ & 0,789 & & \\
\hline Çevremdeki insanlar bu tura katılmamı yadırgamadı. & 0,764 & & \\
\hline \multicolumn{4}{|l|}{ Fiyat } \\
\hline Turun fiyatı bütçeme uygundu. & 0,922 & \multirow{2}{*}{2,060} & \multirow{2}{*}{$\% 14,713$} \\
\hline Ekonomik bir turdu. & 0,917 & & \\
\hline AÇIKLANAN VARYANS & \multicolumn{3}{|c|}{76,440} \\
\hline KAISER-MEYER-OLKIN (KMO) & \multicolumn{3}{|c|}{0,876} \\
\hline BARTLETT TESTI & \multicolumn{3}{|c|}{$\mathrm{p}<0,000$} \\
\hline
\end{tabular}

Analiz sonuçlarında ilk olarak Kaiser-Meyer-Olkin (KMO) örneklem yeterlilik değeri ile Bartlett testi değerleri göz önünde bulundurulmuştur. KMO örneklem ölçüm değeri $(0,876)$ ve Bartlett testi değeri $(\mathrm{p}<0)$ sonuçları, faktör analizinin uygulanabilir olduğunu ifade etmektedir. Yapılan analiz neticesinde "Bu tura katılmak bilgi düzeyimi arttırdı" ile "Fiyatına göre iyi bir hizmet aldım" ifadeleri binişik yük taşıdığı için analizden çıkarılarak 14 ifade ile analiz tekrar gerçekleştirilmiştir. Tablo 1'de yer aldığı gibi faktör analizi uygulanan algılanan değer ölçeğindeki ifadelerin 4 faktöre ayrıldığı tespit edilmiştir. Faktör isimleri, PERVAL ölçeğinin uyarlandığı Tangpattanakit (2017) tarafından yapılan çalışmada olduğu gibi "Kalite", "Duygusal", "Sosyal" ve "Fiyat" olarak adlandırılmıştır. Analiz sonucunda elde edilen faktörler çerçevesinde, 5 ifade ile oluşturulan "kalite" faktörünün varyans açıklama oranının \%26,866 olduğu ortaya çıkmaktadır. 4 ifade ile oluşturulan "duygusal" faktörünün varyans açklama oranı \%19,626 olarak görülmektedir. "Sosyal" olarak isimlendirilen 3 ifadeli faktörün varyans açıklama oranının \%15,235 olduğu saptanmaktadır. Dördüncü ve son faktör olan 2 maddeli "fiyat" faktörünün ise $\% 14,713$ varyans açıklama oranına sahip olduğu görülmektedir. Bu bağlamda 4 faktörün açıklanan varyans oranının $\% 76,440$ olduğu gözlemlenmektedir. Ayrıca orijinalinde fiyat faktörü altında yer alan "Turist rehberinin hizmeti, ödediğim fiyata değgi" ifadesinin, yapılan analiz sonucunda kalite faktörü altında yer aldığı tespit edilmiştir. 


\section{Değişkenlerin Regresyon Analizi Sonuçları ve Hipotez Testleri}

Rehberli turlarda algılanan değerin, akış deneyimi üzerindeki etkisine ilişkin oluşturulan $\mathrm{H} 1$ hipotezi, "Rehberli turlarda algılanan değerin, akış deneyimine etkisi vardır" şeklinde ifade edilmiştir. Tablo 2'deki bulgular doğrultusunda algılanan değerin, akış deneyimi üzerindeki değişimin $\% 40,4$ 'ünü açıkladığı ortaya çıkmaktadır $\left(R^{2}=0,404\right)$. ANOVA testi sonuçlarına göre de bu modelin istatistiksel açıdan anlamlı olduğu görülmektedir ( $F=266,833 ; \mathrm{p}<0,001)$. Ayrıca regresyon katsayılarına göz atıldığında $(B=0,752)$, katılımcıların algılanan değere yönelik algılamalarındaki bir birimlik artışın, akış deneyimini \%75,2 oranında arttırdığ görülmektedir. Bu bağlamda araştırmanın $\mathrm{H} 1$ hipotezi kabul edilmektedir.

Tablo 2. Algılanan Değer ve Akış Deneyiminin Regresyon Analizi Bulguları

\begin{tabular}{|c|c|c|c|c|}
\hline \multirow{2}{*}{ Model 1 } & $\mathbf{R}$ & $\mathbf{R}^{\mathbf{2}}$ & Düzeltilmiş $\mathbf{R}^{\mathbf{2}}$ & Standart Hata \\
\cline { 2 - 5 } & 0,635 & 0,404 & 0,402 & 0,39913 \\
\hline
\end{tabular}

Bağımsız Değişken: Algılanan Değer

\begin{tabular}{|c|c|c|c|c|c|}
\hline \multicolumn{7}{|c|}{ ANOVA } \\
\hline & Kareler Toplamı & df & Ort. Kare & F & Sig. \\
\hline Regresyon & 42,508 & 1 & 42,508 & 266,833 & 0,000 \\
\hline Artık Değer & 62,766 & 394 & 0,159 & & \\
\hline Toplam & 105,274 & 395 & & & \\
\hline
\end{tabular}

Bağımsız Değişken: Algılanan Değer

Bağımlı Değişken: Akış Deneyimi

\begin{tabular}{|c|c|c|c|c|c|}
\hline \multirow{2}{*}{ Model 1 } & \multicolumn{2}{|l|}{$\begin{array}{l}\text { Standardize Edilmemiş } \\
\text { Katsayı }\end{array}$} & $\begin{array}{l}\text { Standardize Edilmiş } \\
\text { Katsayı }\end{array}$ & \multirow{2}{*}{ S } & Sig \\
\cline { 2 - 5 } & B & Std. Hata & BETA & 3,432 & 0,001 \\
\hline Sabit & 0,711 & 0,207 & & 16,335 & 0,000 \\
\hline Algılanan Değer & 0,752 & 0,046 & 0,635 & \\
\hline
\end{tabular}

Bağımlı Değişken: Akış Deneyimi

Tablo 3' de algılanan duygusal değerin akış deneyimindeki etkisinin regresyon analizine yönelik bulguları yer almaktadır. Rehberli turlarda algılanan duygusal değerin, akış deneyimi üzerindeki etkisine ilişkin oluşturulan $\mathrm{H}_{11}$ hipotezi, "Rehberli turlarda algılanan duygusal değerin, akış deneyimine etkisi vardır" şeklinde belirtilmiştir. Tablo 3'de yer almakta olan $\mathrm{R}^{2}$ değerine bakıldığında algılanan duygusal değerin, akış deneyimi üzerindeki değişimin \%34,6'sını açıkladığ 1 görülmektedir. ANOVA testi sonuçlarına göre, incelenen modelin genel olarak anlamlı olduğu ortaya çıkmaktadır $(\mathrm{F}=208,345 ; \mathrm{p}<0,001)$. Regresyon katsayılarına göre de anket katılımcılarının algılanan duygusal değere ilişkin algılamalarındaki bir birimlik artış, akış deneyimini $\% 65,3$ oranında arttırmaktadır $(\mathrm{B}=0,653)$. Bu bulgulara göre araştırmanın $\mathrm{H}_{11}$ hipotezi kabul edilmektedir.

Algılanan sosyal değer ile akış deneyimi arasındaki regresyon analizine yönelik bulgular Tablo 4'te yer almaktadır. Rehberli turlarda algılanan sosyal değerin, akış deneyimi üzerindeki etkisine ilişkin oluşturulan $\mathrm{H}_{12}$ hipotezi, "Rehberli turlarda algılanan sosyal değerin, akış deneyimine etkisi vardır" şeklinde ifade edilmiştir. Tablo 4'teki bulgular doğrultusunda algılanan sosyal değerin, akış deneyimi üzerindeki değişimin $\% 18,6$ 'sını açıkladığı ortaya çıkmaktadır $\left(R^{2}=0,186\right)$. ANOVA testi sonuçlarına göre de bu modelin istatistiksel açıdan anlamlı olduğu görülmektedir ( $\mathrm{F}=89,878$; $\mathrm{p}<0,001)$. Ayrıca regresyon katsayılarına göz atıldığında $(B=0,397)$, katılımcıların algılanan sosyal 
değere yönelik algılamalarındaki bir birimlik artışın, akış deneyimini \%39,7 oranında arttırdığı görülmektedir. Bu bağlamda araştırmanın $\mathrm{H}_{12}$ hipotezi kabul edilmektedir.

Tablo 3. Algılanan Değer (Duygusal) ve Akış Deneyiminin Regresyon Analizi Bulguları

\begin{tabular}{|c|c|c|c|c|c|}
\hline \multirow{2}{*}{ Model 1 } & $\mathbf{R}$ & $\mathbf{R}^{\mathbf{2}}$ & Düzeltilmiş $\mathbf{R}^{\mathbf{2}}$ & Standart Hata & \\
\cline { 2 - 6 } & 0,588 & 0,346 & 0,344 & 0,41806 & \\
\hline
\end{tabular}

Bağımsız Değişken: Algılanan Değer (Duygusal)

\begin{tabular}{|c|c|c|c|c|c|}
\hline \multicolumn{7}{|c|}{ ANOVA } & F & Sig. \\
\hline & Kareler Toplamı & df & Ort. Kare & 208,345 & 0,000 \\
\hline Regresyon & 36,413 & 1 & 36,413 & & \\
\hline Artık Değer & 68,861 & 394 & 0,175 & & \\
\hline Toplam & 105,274 & 395 & & & \\
\hline
\end{tabular}

Bağımsız Değişken: Algılanan Değer (Duygusal)

Bağımlı Değişken: Akış Deneyimi

\begin{tabular}{|c|c|c|c|c|c|}
\hline \multirow{2}{*}{ Model 1 } & \multicolumn{2}{|l|}{$\begin{array}{l}\text { Standardize Edilmemiş } \\
\text { Katsayı }\end{array}$} & $\begin{array}{l}\text { Standardize Edilmiş } \\
\text { Katsayı }\end{array}$ & \multirow{2}{*}{ t } & \multirow{2}{*}{ Sig } \\
\cline { 2 - 6 } & B & Std. Hata & BETA & 4,920 & 0,000 \\
\hline Sabit & 1,040 & 0,211 & & 14,464 & 0,000 \\
\hline $\begin{array}{c}\text { Algılanan Değer } \\
\text { (Duygusal) }\end{array}$ & 0,653 & 0,045 & 0,588 & \\
\hline
\end{tabular}

Bağımlı Değişken: Akış Deneyimi

Tablo 4. Algılanan Değer (Sosyal) ve Akış Deneyiminin Regresyon Analizi Bulguları

\begin{tabular}{|c|c|c|c|c|}
\hline \multirow{2}{*}{ Model 1 } & $\mathbf{R}$ & $\mathbf{R}^{\mathbf{2}}$ & Düzeltilmiş $\mathbf{R}^{\mathbf{2}}$ & Standart Hata \\
\cline { 2 - 5 } & 0,431 & 0,186 & 0,184 & 0,46644 \\
\hline
\end{tabular}

Bağımsız Değişken: Algılanan Değer (Sosyal)

\begin{tabular}{|c|c|c|c|c|c|}
\hline \multicolumn{7}{|c|}{ ANOVA } \\
\hline & Kareler Toplamı & df & Ort. Kare & F & Sig. \\
\hline Regresyon & 19,554 & 1 & 19,554 & 89,878 & 0,000 \\
\hline Artık Değer & 85,720 & 394 & 0,219 & & \\
\hline Toplam & 105,274 & 395 & & & \\
\hline
\end{tabular}

Bağımsız Değişken: Algılanan Değer (Sosyal)

Bağımlı Değişken: Akış Deneyimi

\begin{tabular}{|c|c|c|c|c|c|}
\hline \multirow{2}{*}{ Model 1 } & \multicolumn{2}{|l|}{$\begin{array}{l}\text { Standardize Edilmemiş } \\
\text { Katsayı }\end{array}$} & $\begin{array}{l}\text { Standardize Edilmiş } \\
\text { Katsayı }\end{array}$ & \multirow{2}{*}{ Sig } \\
\cline { 2 - 5 } & B & Std. Hata & BETA & & 0,000 \\
\hline Sabit & 2,295 & 0,189 & & 9,123 & 0,000 \\
\hline $\begin{array}{c}\text { Algilanan Değer } \\
\text { (Sosyal) }\end{array}$ & 0,397 & 0,042 & 0,431 & 9,480 & 0 \\
\hline
\end{tabular}

Bağımlı Değişken: Akış Deneyimi

Tablo 5'te algılanan kalite değerinin akış deneyimi üzerindeki etkisinin regresyon analizine dair sonuçları bulunmaktadır. Rehberli turlarda algılanan kalite değerinin, akış deneyimi üzerindeki etkisine ilişkin oluşturulan $\mathrm{H}_{13}$ hipotezi, "Rehberli turlarda algılanan kalite değerinin, akış deneyimine etkisi vardır" şeklinde ifade edilmiştir. Tablo 5 'te yer almakta olan $\mathrm{R}^{2}$ değerine bakıldığında algılanan duygusal değerin, akış deneyimi üzerindeki değişimin \%33,1'ini açıladığı ortaya çıkmaktadır. ANOVA testi bulgularına göre de modelin anlamlı olduğu ifade edilebilmektedir ( $F=194,808 ; p<0,001)$. Regresyon katsayılarına göre ise anket katılımclarının algilanan kalite değerine yönelik algılamalarındaki bir birimlik artış, akış deneyimini \%51,7 oranında arttırmaktadır $(\mathrm{B}=0,517)$. Bu bulgular neticesinde araştırmanın $\mathrm{H} 13$ hipotezi kabul edilmektedir. 
Tablo 5. Algılanan Değer (Kalite) ve Akış Deneyiminin Regresyon Analizi Bulguları

\begin{tabular}{|c|c|c|c|c|}
\hline \multirow{2}{*}{ Model 1 } & $\mathbf{R}$ & $\mathbf{R}^{\mathbf{2}}$ & Düzeltilmiş $\mathbf{R}^{\mathbf{2}}$ & Standart Hata \\
\cline { 2 - 5 } & 0,575 & 0,331 & 0,329 & 0,42284 \\
\hline
\end{tabular}

Bağımsız Değişken: Algılanan Değer (Kalite)

\begin{tabular}{|c|c|c|c|c|c|}
\hline \multicolumn{7}{|c|}{ ANOVA } \\
\hline & Kareler Toplamı & df & Ort. Kare & F & Sig. \\
\hline Regresyon & 34,830 & 1 & 34,830 & 194,808 & 0,000 \\
\hline Artık Değer & 70,444 & 394 & 0,179 & & \\
\hline Toplam & 105,274 & 395 & & & \\
\hline
\end{tabular}

Bağımsız Değişken: Algılanan Değer (Kalite)

Bağımlı Değişken: Akış Deneyimi

\begin{tabular}{|c|c|c|c|c|c|}
\hline \multirow{2}{*}{ Model 1 } & \multicolumn{2}{|l|}{$\begin{array}{l}\text { Standardize Edilmemiş } \\
\text { Katsayı }\end{array}$} & $\begin{array}{l}\text { Standardize Edilmiş } \\
\text { Katsayı }\end{array}$ & \multirow{2}{*}{ Sig } \\
\cline { 2 - 5 } & B & Std. Hata & BETA & 10,663 & 0,000 \\
\hline Sabit & 1,774 & 0,166 & & 13,957 & 0,000 \\
\hline $\begin{array}{c}\text { Algilanan Değer } \\
\text { (Kalite) }\end{array}$ & 0,517 & 0,037 & 0,575 & \\
\hline
\end{tabular}

Bağımlı Değişken: Akış Deneyimi

Tablo 6'da algılanan fiyat değerinin akış deneyimi üzerindeki etkisine ilişkin regresyon analizinin sonuçları yer almaktadır. Algılanan fiyat değerinin, akış deneyimi üzerindeki etkisine yönelik oluşturulan $\mathrm{H} 14$ hipotezi, "Rehberli turlarda algılanan fiyat değerinin, akış deneyimine etkisi vardır" şeklinde ifade edilmiştir. Tablo 6 ' daki bulgular doğrultusunda algılanan fiyat değeri, akış deneyimi üzerindeki değişimin $\% 6,6$ 'sını açıklamaktadır $\left(\mathrm{R}^{2}=0,064\right)$. ANOVA testi sonuçlarına göre de bu modelin anlamlı olduğu görülmektedir $(F=27,969 ; p<0,001)$. Ayrıca regresyon katsayılarına göz atıldığında, katılımcıların algılanan fiyat değerine yönelik algılamalarındaki bir birimlik artışın, akış deneyimini \%16,5 oranında arttırdığı görülmektedir (B=0,165). Bu bağlamda araştırmanın $\mathrm{H}_{14}$ hipotezi kabul edilmektedir.

Tablo 6. Algılanan Değer (Fiyat) ve Akış Deneyiminin Regresyon Analizi Bulguları

\begin{tabular}{|c|c|c|c|c|}
\hline \multirow{2}{*}{ Model 1 } & $\mathbf{R}$ & $\mathbf{R}^{\mathbf{2}}$ & Düzeltilmiş $\mathbf{R}^{\mathbf{2}}$ & Standart Hata \\
\cline { 2 - 5 } & 0,275 & 0,066 & 0,064 & 0,49948 \\
\hline
\end{tabular}

Bağımsız Değişken: Algılanan Değer (Fiyat)

\begin{tabular}{|c|c|c|c|c|c|}
\hline \multicolumn{7}{|c|}{ ANOVA } \\
\hline & Kareler Toplamı & df & Ort. Kare & F & Sig. \\
\hline Regresyon & 6,978 & 1 & 6,978 & 27,969 & 0,000 \\
\hline Artık Değer & 98,296 & 394 & 0,249 & & \\
\hline Toplam & 105,274 & 395 & & & \\
\hline
\end{tabular}

Bağımsız Değişken: Algılanan Değer (Fiyat)

Bağımlı Değişken: Akış Deneyimi

\begin{tabular}{|c|c|c|c|c|c|}
\hline \multirow{2}{*}{ Model 1 } & \multicolumn{2}{|l|}{$\begin{array}{l}\text { Standardize Edilmemiş } \\
\text { Katsayı }\end{array}$} & $\begin{array}{l}\text { Standardize Edilmiş } \\
\text { Katsayı }\end{array}$ & \multirow{2}{*}{ t } & Sig \\
\cline { 2 - 5 } & B & Std. Hata & BETA & 25,346 & 0,000 \\
\hline Sabit & 3,383 & 0,133 & & 5,289 & 0,000 \\
\hline $\begin{array}{c}\text { Algılanan Değer } \\
\text { (Fiyat) }\end{array}$ & 0,165 & 0,031 & 0,257 & \\
\hline
\end{tabular}

Bağımlı Değişken: Akış Deneyimi

Bu bulgular doğrultusunda, birim artışıyla akış deneyimini en çok arttıran bağımsız değişkenler sirasıyla algılanan duygusal değer $(B=0,653)$, algilanan kalite değeri $(B=0,517)$, algilanan sosyal değer $(B=0,397)$ ve algılanan fiyat değeri $(B=0,165)$ olarak ortaya çıkmaktadır. 
Algılanan değerin davranışsal niyet üzerindeki etkisinin regresyon analizi sonuçlarına Tablo $7^{\prime}$ de yer verilmiştir. Algılanan değerin, davranışsal niyet üzerindeki etkisine yönelik oluşturulan $\mathrm{H}_{2}$ hipotezi, "Rehberli turlarda algzlanan değerinin, davranışsal niyete etkisi vardır" şeklinde ifade edilmiştir. Tablo 7'deki bulgular doğrultusunda algılanan değer, davranışsal niyete ilişkin değişimin \%51,4'ünü açıklamaktadır $\left(\mathrm{R}^{2}=0,514\right)$. ANOVA testi sonuçları ise bu modelin anlamlı olduğunu göstermektedir ( $F=417,127 ; \mathrm{p}<0,001)$. Ayrıca regresyon katsayıları dikkate alındığında, katılımcıların algılanan kalite değerine yönelik algılamalarındaki bir birimlik artışın, davranışsal niyeti \%102,2 oranında arttırdığı görülmektedir ( $\mathrm{B}=1,022)$. Bu bağlamda araştırmanın $\mathrm{H}_{2}$ hipotezi kabul edilmektedir.

Tablo 7. Algılanan Değer ve Davranışsal Niyetin Regresyon Analizi Bulguları

\begin{tabular}{|c|c|c|c|c|}
\hline \multirow{2}{*}{ Model 1 } & $\mathbf{R}$ & $\mathbf{R}^{\mathbf{2}}$ & Düzeltilmiş R & Standart Hata \\
\cline { 2 - 5 } & 0,717 & 0,514 & 0,513 & 0,43397 \\
\hline
\end{tabular}

Bağımsız Değişken: Algılanan Değer

\begin{tabular}{|c|c|c|c|c|c|}
\hline \multicolumn{7}{|c|}{ ANOVA } \\
\hline & Kareler Toplamı & df & Ort. Kare & F & Sig. \\
\hline Regresyon & 78,558 & 1 & 78,558 & 417,127 & 0,000 \\
\hline Artık Değer & 74,202 & 394 & 0,188 & & \\
\hline Toplam & 152,760 & 395 & & & \\
\hline
\end{tabular}

Bağımsız Değişken: Algılanan Değer

Bağımlı Değişken: Davranışsal Niyet

\begin{tabular}{|c|c|c|c|c|c|}
\hline \multirow{2}{*}{ Model 1 } & \multicolumn{2}{|l|}{$\begin{array}{l}\text { Standardize Edilmemiş } \\
\text { Katsayı }\end{array}$} & $\begin{array}{l}\text { Standardize Edilmiş } \\
\text { Katsayı }\end{array}$ & \multirow{2}{*}{ S } & \multirow{2}{*}{ Sig } \\
\cline { 2 - 4 } & B & Std. Hata & BETA & & \\
\hline Sabit & $-0,143$ & 0,225 & & $-0,635$ & 0,526 \\
\hline Algılanan Değer & 1,022 & 0,050 & 0,717 & 20,424 & 0,000 \\
\hline
\end{tabular}

Bağımlı Değişken: Davranışsal Niyet

Tablo 8' de algilanan duygusal değerin davranışsal niyet üzerindeki etkisinin regresyon analizine yönelik bulguları yer almaktadır. Rehberli turlarda algılanan duygusal değerin, davranışsal niyet üzerindeki etkisine ilişkin oluşturulan $\mathrm{H}_{21}$ hipotezi, "Rehberli turlarda algılanan duygusal değerin, davranışsal niyete etkisi vardır" şeklinde ifade edilmiştir. Tablo $8^{\prime}$ de yer alan $\mathrm{R}^{2}$ oranı incelendiğinde algılanan duygusal değerin, davranışsal niyetteki değişikliğin \%47,3'ünü ifade ettiği ortaya çıkmaktadır. ANOVA testi sonuçlarına göre ilgili modelin anlamlı olduğu ortaya çıkmaktadır ( $\mathrm{F}=353,145 ; \mathrm{p}<0,001)$. Regresyon katsayılarına göre de anket katılımcılarının algılanan duygusal değere ilişkin algılamalarındaki bir birimlik artış, davranışsal niyeti \%91,9 oranında arttırmaktadır $(B=0,919)$. Söz konusu bulgular ışığında araştırmadaki $\mathrm{H}_{21}$ hipotezi kabul edilmektedir.

Algılanan sosyal değerin davranışsal niyetteki etkisinin regresyon analizine yönelik bulgulara Tablo 9'da yer verilmektedir. Algılanan sosyal değerin akış deneyimi üzerindeki etkisini belirlemek için oluşturulan $\mathrm{H}_{22}$ hipotezi "Rehberli turlarda algllanan sosyal değerin, davranışsal niyete etkisi vardır" şeklinde belirtilmiştir. Tablo 9'a göre davranışsal niyete ilişkin değişimin \%18,1'i algılanan sosyal değer ile açıklanabilmektedir $\left(\mathrm{R}^{2}=0,181\right)$. ANOVA sonuçlarına bakıldığında da bu modelin anlamlı olduğu görülmektedir ( $F=87,082 ; p<0,001)$. Ayrıca regresyon katsayılarına göre algılanan sosyal değerin bir birimlik artışı, davranışsal niyet üzerinde $\% 47,2$ oranında artış sağlamaktadır $(B=0,472)$. Bu bulgular neticesinde algılanan sosyal değerin davranışsal niyet üzerinde anlamlı bir etkiye sahip olduğu tespit edilerek araştırmanın $\mathrm{H}_{22}$ hipotezi kabul edilmektedir. 
Tablo 8. Algılanan Değer (Duygusal) ve Davranışsal Niyetin Regresyon Analizi Bulguları

\begin{tabular}{|c|c|c|c|c|}
\hline \multirow{2}{*}{ Model 1 } & $\mathbf{R}$ & $\mathbf{R}^{\mathbf{2}}$ & Düzeltilmiş $\mathbf{R}^{\mathbf{2}}$ & Standart Hata \\
\cline { 2 - 5 } & 0,688 & 0,473 & 0,471 & 0,45217 \\
\hline
\end{tabular}

Bağımsız Değişken: Algılanan Değer (Duygusal)

\begin{tabular}{|c|c|c|c|c|c|}
\hline \multicolumn{7}{|c|}{ ANOVA } \\
\hline & Kareler Toplamı & df & Ort. Kare & F & Sig. \\
\hline Regresyon & 72,203 & 1 & 72,203 & 353,145 & 0,000 \\
\hline Artık Değer & 80,557 & 394 & 0,204 & & \\
\hline Toplam & 152,760 & 395 & & & \\
\hline
\end{tabular}

Bağımsız Değişken: Algılanan Değer (Duygusal)

Bağımlı Değişken: Davranışsal Niyet

\begin{tabular}{|c|c|c|c|c|c|}
\hline \multirow{2}{*}{ Model 1 } & \multicolumn{2}{|l|}{$\begin{array}{l}\text { Standardize Edilmemiş } \\
\text { Katsayı }\end{array}$} & $\begin{array}{l}\text { Standardize Edilmiş } \\
\text { Katsayı }\end{array}$ & \multirow{2}{*}{ Sig } \\
\cline { 2 - 5 } & B & Std. Hata & BETA & 0,687 & 0,492 \\
\hline Sabit & 0,157 & 0,229 & & 18,792 & 0,000 \\
\hline $\begin{array}{c}\text { Algılanan Değer } \\
\text { (Duygusal) }\end{array}$ & 0,919 & 0,049 & 0,688 & \\
\hline
\end{tabular}

Bağımlı Değişken: Davranışsal Niyet

Tablo 9. Algılanan Değer (Sosyal) ve Davranışsal Niyetin Regresyon Analizi Bulguları

\begin{tabular}{|l|l|l|l|l|}
\hline \multirow{2}{*}{ Model 1 } & $\mathbf{R}$ & $\mathbf{R}^{2}$ & Düzeltilmiş $\mathbf{R}^{\mathbf{2}}$ & Standart Hata \\
\cline { 2 - 5 } & 0,425 & 0,181 & 0,179 & 0,56350 \\
\hline
\end{tabular}

Bağımsız Değişken: Algılanan Değer (Sosyal)

\begin{tabular}{|l|l|l|l|l|l|}
\hline \multicolumn{9}{|c|}{ ANOVA } \\
\hline & Kareler Toplamı & df & Ortalama Kare & F & Sig. \\
\hline Regresyon & 27,651 & 1 & 27,651 & 87,082 & 0,000 \\
\hline Artık Değer & 125,108 & 394 & 0,318 & & \\
\hline Toplam & 152,760 & 395 & & & \\
\hline
\end{tabular}

Bağımsız Değişken: Algılanan Değer (Sosyal)

Bağımlı Değişken: Davranışsal Niyet

\begin{tabular}{|l|l|l|l|l|l|}
\hline \multirow{2}{*}{ Model 1 } & \multicolumn{2}{|l|}{$\begin{array}{l}\text { Standardize Edilmemiş } \\
\text { Katsayı }\end{array}$} & $\begin{array}{l}\text { Standardize Edilmiş } \\
\text { Katsayı }\end{array}$ & \multirow{2}{*}{ t } & \multirow{2}{*}{ Sig } \\
\cline { 2 - 6 } & B & Std. Hata & BETA & 10,120 & 0,000 \\
\hline Sabit & 2,315 & 0,229 & & 9,332 & 0,000 \\
\hline $\begin{array}{l}\text { Algilanan Değer } \\
\text { (Sosyal) }\end{array}$ & 0,472 & 0,051 & 0,425 & \\
\hline
\end{tabular}

Bağımlı Değişken: Davranışsal Niyet

Tablo 10'da algılanan kalite değerinin davranışsal niyet üzerindeki etkisinin regresyon analizi bulguları bulunmaktadır. Algılanan kalite değerinin, akış deneyimi üzerindeki etkisine yönelik oluşturulan $\mathrm{H}_{23}$ hipotezi, "Rehberli turlarda algılanan kalite değerinin, davranışsal niyete etkisi vardır" şeklinde ifade edilmiştir. Tablo 10'daki bulgular doğrultusunda algılanan kalite değeri, davranışsal niyete ilişkin değişimin $\% 43,2^{\prime}$ sini açıklamaktadır $\left(R^{2}=0,432\right)$. ANOVA testi sonuçları ise bu modelin anlamlı olduğunu göstermektedir $(\mathrm{F}=299,110 ; \mathrm{p}<0,001)$. Ayrıca regresyon katsayıları dikkate alındığında, katılımcıların algılanan kalite değerine yönelik algılamalarındaki bir birimlik artışın, davranışsal niyeti \%71,2 oranında arttırdığ görülmektedir $(B=0,712)$. Bu bağlamda araştırmanın $\mathrm{H}_{2} 3$ hipotezi kabul edilmektedir. 
Tablo 10. Algılanan Değer (Kalite) ve Davranışsal Niyetin Regresyon Analizi Bulguları

\begin{tabular}{|c|c|c|c|c|}
\hline \multirow{2}{*}{ Model 1 } & $\mathbf{R}$ & $\mathbf{R}^{\mathbf{2}}$ & Düzeltilmiş $\mathbf{R}^{\mathbf{2}}$ & Standart Hata \\
\cline { 2 - 5 } & 0,657 & 0,432 & 0,430 & 0,46947 \\
\hline
\end{tabular}

Bağımsız Değişken: Algılanan Değer (Kalite)

\begin{tabular}{|c|c|c|c|c|c|}
\hline \multicolumn{7}{|c|}{ ANOVA } \\
\hline & Kareler Toplamı & df & Ortalama Kare & F & Sig. \\
\hline Regresyon & 65,923 & 1 & 65,923 & 299,110 & 0,000 \\
\hline Artık Değer & 86,837 & 394 & 0,220 & & \\
\hline Toplam & 152,760 & 395 & & & \\
\hline
\end{tabular}

Bağımsız Değişken: Algılanan Değer (Kalite)

Bağımlı Değişken: Davranışsal Niyet

\begin{tabular}{|c|c|c|c|c|c|}
\hline \multirow{2}{*}{ Model 1 } & \multicolumn{2}{|l|}{$\begin{array}{l}\text { Standardize Edilmemiş } \\
\text { Katsayı }\end{array}$} & $\begin{array}{l}\text { Standardize Edilmiş } \\
\text { Katsayı }\end{array}$ & \multirow{2}{*}{ Sig } \\
\cline { 2 - 5 } & B & Std. Hata & BETA & 6,848 & 0,000 \\
\hline Sabit & 1,265 & 0,185 & & 17,295 & 0,000 \\
\hline $\begin{array}{c}\text { Algilanan Değer } \\
\text { (Kalite) }\end{array}$ & 0,712 & 0,041 & 0,657 & \\
\hline
\end{tabular}

Bağımlı Değişken: Davranışsal Niyet

Algılanan fiyat değerinin davranışsal niyete etkisinin regresyon analizi bulguları Tablo 11'de belirtilmektedir. Rehberli turlarda algilanan fiyat değerinin, davranışsal niyet üzerindeki etkisine ilişkin oluşturulan $\mathrm{H}_{2} 4$ hipotezi, "Rehberli turlarda algılanan fiyat değerinin, davranışsal niyete etkisi vardır" şeklinde belirtilmiştir. Tablo $11^{\prime}$ deki bulgular neticesinde algılanan fiyat değerinin, davranışsal niyete ilişkin değişimin $\% 9,8^{\prime}$ ini açıkladığı görülmektedir $\left(\mathrm{R}^{2}=0,098\right)$. ANOVA testi sonuçları ise bu modelin istatistiksel açıdan anlamlı olduğu ifade etmektedir ( $F=42,740 ; p<0,001)$. Bununla birlikte regresyon katsayılarına $(B=0,242)$ bakıldığında, katılımcıların algılanan sosyal değere yönelik algılamalarındaki bir birimlik artışın, davranışsal niyeti \%24,2 oranında arttırdığı görülmektedir. Bu bağlamda araştırmanın $\mathrm{H}_{2} 4$ hipotezi kabul edilmektedir.

Tablo 11. Algılanan Değer (Fiyat) ve Davranışsal Niyetin Regresyon Analizi Bulguları

\begin{tabular}{|c|c|c|c|c|}
\hline \multirow{2}{*}{ Model 1 } & $\mathbf{R}$ & $\mathbf{R}^{\mathbf{2}}$ & Düzeltilmiş $\mathbf{R}^{\mathbf{2}}$ & Standart Hata \\
\cline { 2 - 5 } & 0,313 & 0,098 & 0,096 & 0,59142 \\
\hline
\end{tabular}

Bağımsız Değişken: Algılanan Değer (Fiyat)

\begin{tabular}{|c|c|c|c|c|c|}
\hline \multicolumn{7}{|c|}{ ANOVA } \\
\hline & Kareler Top. & df & Ort. Kare & F & Sig. \\
\hline Regresyon & 14,949 & 1 & 14,949 & 42,740 & 0,000 \\
\hline Artık Değer & 137,811 & 394 & 0,350 & & \\
\hline Toplam & 152,760 & 395 & & & \\
\hline
\end{tabular}

Bağımsız Değişken: Algılanan Değer (Fiyat)

Bağımlı Değişken: Davranışsal Niyet

\begin{tabular}{|c|c|c|c|c|c|}
\hline \multirow{2}{*}{ Model 1 } & \multicolumn{2}{|l|}{$\begin{array}{l}\text { Standardize Edilmemiş } \\
\text { Katsayı }\end{array}$} & $\begin{array}{l}\text { Standardize Edilmiş } \\
\text { Katsayı }\end{array}$ & t & Sig \\
\cline { 2 - 5 } B & Std. Hata & BETA & 21,627 & 0,000 \\
\hline Sabit & 3,418 & 0,158 & & 6,538 & 0,000 \\
\hline $\begin{array}{c}\text { Algilanan Değer } \\
\text { (Fiyat) }\end{array}$ & 0,242 & 0,037 & 0,313 & \\
\hline
\end{tabular}

Bağımlı Değişken: Davranışsal Niyet

$\mathrm{Bu}$ bulgular 1şığında, birim artışıyla davranışsal niyeti en çok arttıran bağımsız değişkenler sirasiyla algılanan duygusal değer $(B=0,919)$, algilanan kalite değeri $(B=0,712)$, algilanan sosyal değer $(B=0,472)$ ve algılanan fiyat değeri $(B=0,242)$ olarak tespit edilmiştir. 
Akış deneyiminin davranışsal niyetteki etkisinin regresyon analizine yönelik bulgularına Tablo 12 ' de yer verilmektedir. Rehberli turlarda akış deneyiminin, davranışsal niyet üzerindeki etkisine ilişkin belirlenen $\mathrm{H} 3$ hipotezi, "Rehberli turlarda akış deneyiminin, davranışsal niyete etkisi vardır" şeklinde ifade edilmiştir. Tablo $12^{\prime}$ de belirtilen $\mathrm{R}^{2}$ değeri dikkate alındığında akış deneyiminin $\% 40,4$ oranında davranışsal niyetteki değişikliği ifade ettiği tespit edilmiştir. ANOVA testi sonuçlarına göre ilgili modelin anlamlı olduğu görülmektedir ( $F=267,341 ; p<0,001)$. Regresyon katsayılarına göre ise anket katılımcılarının akış deneyimine yönelik algılamalarındaki bir birimlik artışın, davranışsal niyeti $\% 76,6$ oranında arttırdığı görülmektedir ( $\mathrm{B}=0,766)$. Bu bulgular dahilinde araştırmanın $\mathrm{H} 3$ hipotezi kabul edilmektedir.

Tablo 12. Akış Deneyimi ve Davranışsal Niyet Arasındaki Regresyon Analizi Bulguları

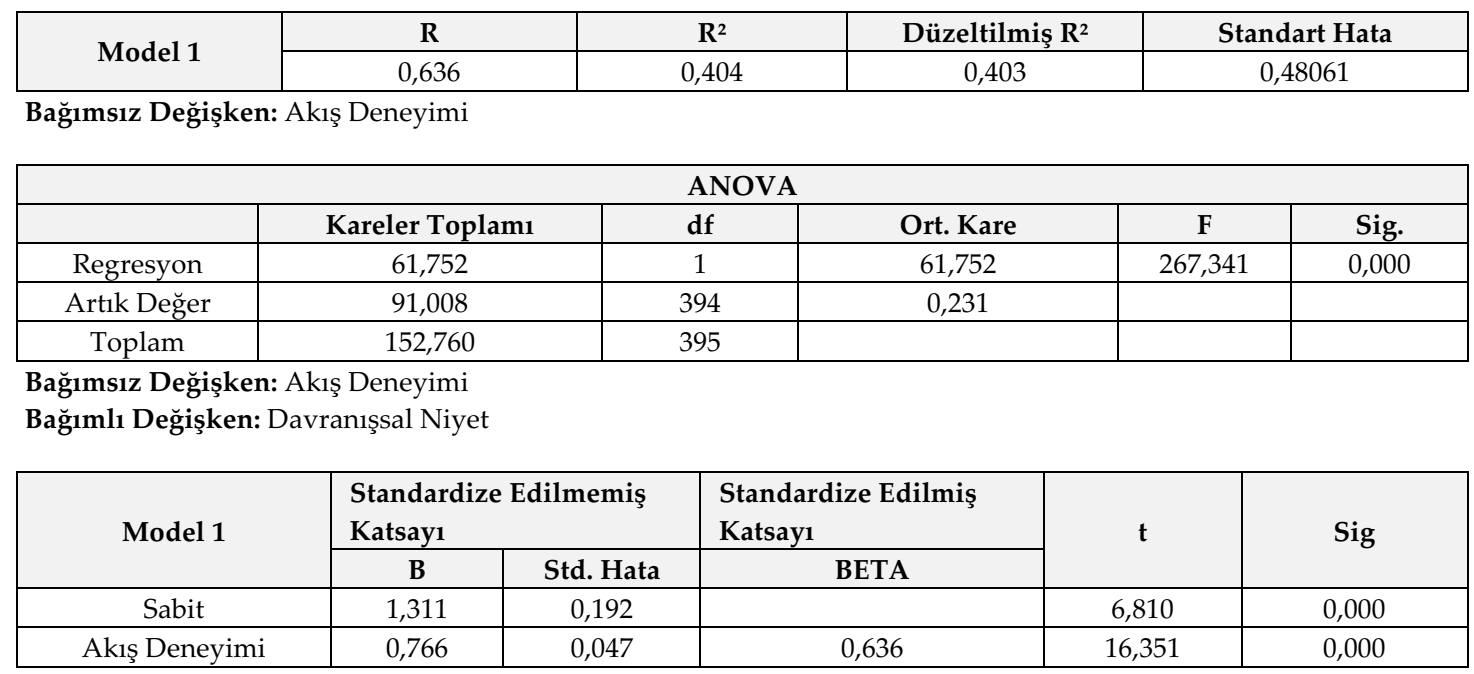

Bağımlı Değişken: Davranışsal Niyet

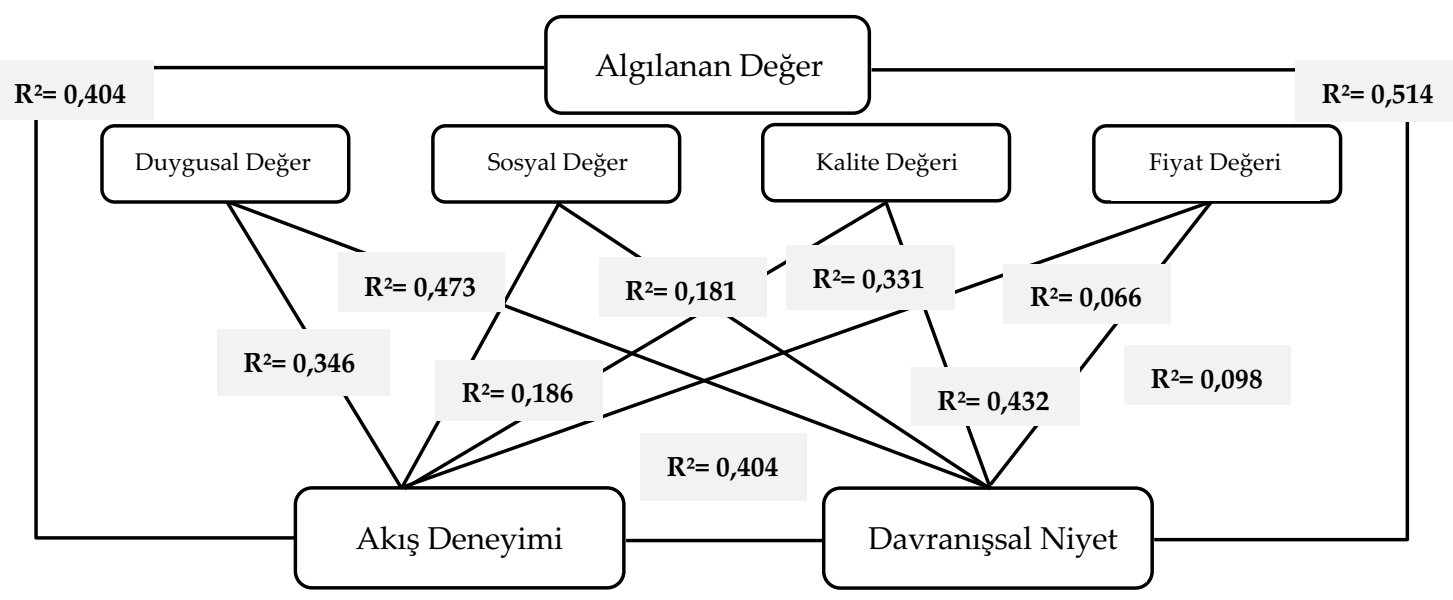

Şekil 2. Araştırmanın Sonuç Modeli

Tüm veriler ışığında duygusal, kalite, sosyal ve fiyat açısından olumlu algılara sahip katılımcıların akış ile mutlu bir deneyim edindikleri ve aynı zamanda algılanan değer ile akış deneyiminin etkisiyle olumlu yorumda bulunma, tavsiye etme ve tekrar ziyaret etme gibi olumlu davranışsal niyetlerin oluşmasını sağladığı sonucuna varılarak, çalışmanın amaçları doğrultusunda belirlenen 11 hipotez kabul edilmiştir. Araştırmanın sonuç modeli Şekil 2'de yer almaktadır. 


\section{TARTIŞMA, SONUÇ ve ÖNERİLER}

Tüm bulgular doğrultusunda, Çanakkale Savaşları Gelibolu Tarihi Alanı'nda gerçekleştirilen rehberli turlarda, katılımcıların başta duygusal ve kalite olarak algıladıkları değerlerin yüksek olduğu ve bu algılamalarla şekillenen sosyo-psikolojik durumun getirdiği mutluluk ve memnuniyetle katılımcılarda akış deneyimi yaşattı̆̆ı, bu bağlamda algılanan değerin akış deneyimini doğrudan etkilediği görülmektedir. Kim ve Thapa (2018) tarafından yapılan çalışmada da algılanan değerin kalite değeri, sosyal değeri ve duygusal değerinin akış deneyimini ve müşteri memnuniyetini önemli ölçüde etkilediği ortaya çıkmıştır. Benzer sonuca varan Dülger (2019) de turistlerin algılarının memnuniyet ve davranışsal niyete olumlu yönde etkisi olduğunu, turist memnuniyetinin olumlu davranışsal niyetlere yol açtığını belirtmiştir.

Akış deneyiminin getirdiği mutluluk, haz gibi duyguların hizmete yönelik değerlendirmeleri etkilemesiyle katılımcıların olumlu davranışsal niyetler sergilediği; özellikle tavsiyeye ve tekrar ziyarete yönelik niyetin öne çıktığı tespit edilmiştir. Akış deneyiminin, davranışsal niyetin tekrar ziyaret niyeti boyutunu etkilediği, Karaca'nın (2018) yüksek lisans tezinde de ortaya konulmuş̧tur. Ayrıca katılımcıların algıladıkları değerlerin de doğrudan kalite ve memnuniyet düzeyiyle şekillenen davranışsal niyetleri doğru oranda etkilediği sonucuna varılabilmektedir. Akkılıç ve Varol'un (2015) çalışmasında, turistin algılanan değer boyutlarının, davranışsal niyete olumlu ve anlamlı bir etkisinin olduğu sonucuna varılmıştır. Benzer sonuca varılan İlban ve diğerlerinin (2016) çalışmasında, algılanan hizmet kalitesinin müşteri memnuniyetinde olumlu ve anlamlı bir etki oluşturduğu; müşteri memnuniyetinin de davranışsal niyetlere olumlu ve anlamlı bir etki meydana getirdiği görülmüştür. Algılanan değer, akış deneyimi ve davranışsal niyet arasındaki olumlu ve anlamlı ilişki ise Çeşmeci'nin (2018) doktora tezi sonuçlarıyla benzerlik taşımaktadır.

Çalışmadan elde edilen sonuçlar doğrultusunda; gelecekteki çalışmalara, turist rehberlerine, kamu kurumlarına, Turist Rehberleri Birliği'ne (TUREB), turist rehberleri meslek odalarına ve seyahat acentalarına birtakım öneriler sunulmaktadır. Çalışmada yer alan araştırma modeli farklı turistik deneyimlere yönelik araştırmalarda kullanılarak elde edilen sonuçlar karşılaştırılabilir. Ayrıca savaş alanları gibi milli ve manevi değerlerin yoğun hissedildiği destinasyonlara yapılan turlarda, turist rehberinin hikayeleştirme teknikleri ile akış deneyimi veya farklı değişkenler arasındaki ilişkinin inceleneceği çalışmalar yapılabilir. Bununla birlikte, Covid-19 salgını nedeniyle turistik ürünler bazında organize edilen "temassız turlar, çadır konaklamalı turlar" gibi farklı turizm deneyimleri üzerine, algılanan değer boyutlarından biri olan epistemik değere yönelik araştırmalar yapılabilir.

Ankete katılım sağlayan turistlerin tura dair kalite algılarının, turist rehberinin bilgi ve hizmet düzeyinden etkilendiği bulgular arasında görülmektedir. Usullu'nun (2019) çalışmasında da turist rehberlerine yönelik algılanan hizmet kalitesinin davranışsal niyetler üzerinde önemli etkisi olduğu sonucuna varılmıştır. Nitekim turist rehberlerinin, Tarihi Alan'da gerçekleştirdikleri turlarda anlatımlarını hikayeleştirerek ve yorumlayarak anlatım içeriklerini zenginleştirmeleri gerekmektedir. Ayrıca Tarihi Alan'a gerçekleştirilen turlarda, tur programının yeterliliğine dair düşük oranda olumlu cevaplar verildiği için turist rehberlerinin, konaklamalı tur programları hazırlayarak bu turların satışını gerçekleştirmeleri için seyahat acentalarını teşvik etmeleri faydalı olabilir.

Anket katılımcılarının bölgeyi ziyaret etmelerindeki etkenlerin başında arkadaş/akraba tavsiyesi olduğu ve reklam etkeninin en düşük etken olarak ortaya çıktığı görülmektedir. Nitekim Çanakkale İl Kültür ve Turizm Müdürlüğü ile Çanakkale Savaşları Gelibolu Tarihi Alan 
Başkanlığı tarafından bölgenin özellikle turist rehberi eşliğinde ziyaret edilmesine yönelik çeşitli reklam çalışmaları yapılması, bölgeye bireysel gelen ziyaretçilerin rehberli tura katılmaları için teşvik edilmeleri katkı sağlayabilir.

Çalışmanın sonuçları bağlamında, katılımcıların bölgeyi ziyaret deneyimlerinden memnun kalmaları, keyifli olduğunu düşünmeleri, olumlu yorum, tavsiye ve tekrar ziyaret gibi davranışlar göstermelerinde rehberli turların önemli olduğu ortaya konulmuştur. Bu değerlendirmelerde de turist rehberinin bilgisinin önemli bir yer edindiği tespit edilmiştir. Nitekim Turist Rehberleri Birliği denetiminde, Çanakkale Bölgesel Turist Rehberleri Odası'nın yürütücülüğünde ve diğer illerdeki meslek odalarının işbirliğiyle Gelibolu Tarihi Alanı'na yönelik uzmanlık eğitimlerinin sıklaştırılmasıyla, bölgede çalışmak isteyen rehberlerin bilgi ve pratiğe dair kendilerini geliştirmelerine imkan oluşturulabilir.

Katılımcıların kalite algılarına ilişkin sonuçlarda tur programının içeriğinin yeterliliğini belirten ifade en düşük ortalamaya sahip ifade olarak ortaya çıkmaktadır. Ayrıca akış deneyimine yönelik ifadelerde mekânların yeterince gezilebildiğine, zamanın iyi kullanıldığına dair olan ifade düşük ortalamaya sahip olan ifadeler arasındadır. Bu duruma, bölgeye ağırlıklı olarak uzak şehirlerden günübirlik turların düzenlenmesinden dolayı programın ve zamanın kısıtlı olmasının neden olduğu düşünülmektedir. Nitekim seyahat acentalarının bölgeye yönelik konaklamalı programları sıklaştırmaları ve Gelibolu Tarihi Alanı'na tam gün ayrılacak şekilde program düzenlemeleri önerilmektedir. Katılımcıların, bölgeyi ziyaret faktörleri arasında turist rehberinin ve daha önceki tur deneyiminin de önemli bir yer tuttuğu görülmektedir. Bu noktada seyahat acentalarının Gelibolu Tarihi Alanı'nın dahil olduğu tur programlarını, turu gerçekleştirecek turist rehberinin adıyla satışa çıkarmaları katılım sayısının artmasını sağlayabilir.

\section{KAYNAKÇA}

Akkılıç, M. E. ve Varol, İ. (2015). Turist Algılarının Davranışsal Niyetler Üzerindeki Etkisi: Edremit Körfezi Örneği, International Review of Economics and Management, 1(3): 14-38.

Altıntaş, V., Türkmendağ, Z. ve Türkmendağ, T. (2017). Tanıtım ve İmaj Oluşturma Faaliyetlerinde Turist Rehberleri, (Editör) Güzel, F. Ö., Altıntaş, V. ve Şahin, İ.: Turist Rehberliği Araştırmaları Öngörüler ve Uygulamalar içinde (ss. 267-289) Ankara: Detay Yayıncllık.

Anderson, E., Fornell, C. and Lehmann, D. (1994). Customer Satisfaction, Market Share and Profitability: Findings from Sweden, Journal of Marketing, 58(3): 53-66.

Asmadili, V. U. (2015). Paket Turlarda Müşteri Memnuniyeti Arttırma Aracı Olarak Algllanan Riskin Azaltılmasında Turist Rehberinin Rolü, Yayınlanmamış Yüksek Lisans Tezi, Balıkesir Üniversitesi, Balıkesir.

Baker, A. D. and Crompton, L. J. (2000). Quality, Satisfaction and Behavioral Intentions, Annals of Tourism Research, 27(3): 785-804.

Bekar, T. (2012). Algılanan Değerin Alg̨lanan Marka Üzerindeki Etkisi, Yayımlanmamış Yüksek Lisans Tezi, Sakarya Üniversitesi, Sakarya.

Bigne, J. E., Sanchez, M. I. and Sanchez, J. (2001). Tourism Image, Evaluation Variables and After Purchase Behaviour: Inter-relationship, Tourism Management, 22(6): 607-616.

Chen, J. S. and Gürsoy, D. (2001). An Investigation of Tourists' Destination Loyalty and Preferences, International Journal of Contemporary Hospitality Management, 13(2): 79-85.

Coşkun, R., Altunışık, R., Bayraktaroğlu, S. ve Yıldırım, E. (2015). Sosyal Bilimlerde Nitel Araştırma Yöntemleri: SPSS uygulamalı. (8. Basım). Sakarya: Sakarya Yayıncilık. 
Csikszentmihalyi, M. (1990). Flow: The Psychology of Optimal Experience. Amerika Birleşik Devletleri: Harper \& Row Publisher.

Csikszentmihalyi, M. (2005). Akış: Mutluluk Bilimi. (Çeviren, Kunt Akbaş, S.) Ankara: HYB Yayıncilik.

Çeşmeci, N. (2018). Yürüyüş Deneyimine Yönelik Akış Durumunun Alģılanan Değere ve Davranışsal Niyete Etkisi, Yayımlanmamış Doktora Tezi, Mersin Üniversitesi, Mersin.

Çetinkaya, M. Y. and Öter, Z. (2016). Role of Tour Guides on Tourist Satisfaction Level in Guided Tours and Impact on Re-visiting Intention: A Research in Istanbul, European Journal of Tourism, Hospitality and Recreation, 7(1): 40-54.

Çetinkaya, Ö. (2016). Kruvaziyer Turizmi Katılımcılarının Deneyimleri, Memnuniyetleri ve Davranışsal Niyetleri, Yayımlanmamış Yüksek Lisans Tezi, Ankara Üniversitesi, Ankara.

Dodds, W. B., Monroe, K. B. and Grewal, D. (1991). Effects of Price, Brand, and Store Information on Buyers' Product Evaluations, Journal of Marketing Research, 28(3): 307-319.

Dülger, A. S. (2019). Ziyaretçilerin Otantiklik Algılarının Algılanan Değer, Memnuniyet ve Davranışsal Niyet Düzeylerine Etkisi: Hamamönü Örneği, Yayımlanmamış Yüksek Lisans Tezi, Gazi Üniversitesi, Ankara.

Filep, S. (2007). 'Flow', Sightseeing, Satisfaction and Personal Development: Exploring Relationships via Positive Psychology. Global Conference on Council for Australian University Tourism and Hospitality Education (CAUTHE): Tourism-Past Achievements, Future Challenges, 11-14 February 2007, Sidney, Austraila.

Filep, S. (2008). Applying the Dimensions of Flow to Explore Visitor Engagement and Satisfaction, Visitor Studies, 11(1): 90-108.

Filep, S. (2012). The Positive Psychology and Tourism, (Editör) Uysal, M., Perdue, R. and Sirgy, M. J.: Handbook of Tourism and Quality-of-Life Research: Enhancing the Lives of Tourists and Residents of Host Communities içinde (ss. 31-50) Netherlands: Springer.

Fishbein, M. and Ajzen, I. (1975). Belief, Attitude, Intention and Behavior: An Introduction to Theory and Research Reading. Amerika Birleşik Devletleri: Addison-Wesley Publishing Company'den aktaran Dalkılıç, F. (2012). Algılanan Destinasyon İmajı ve Tatminin Davranışsal Niyet Üzerindeki Etkisi: Kapadokya Örneği, Yayımlanmamış Yüksek Lisans Tezi, Nevşehir Üniversitesi, Nevşehir.

Güriş, S. ve Astar, M. (2015). Bilimsel Araştırmalarda SPSS ile İstatistik. İstanbul: Der Yayınları.

https://catab.ktb.gov.tr/TR-159996/faaliyet-raporlari.html [Erişim Tarihi: 28.02.2021].

İlban, M. O., Bezirgan, M. ve Çolakoğlu, F. (2016). Termal Otellerde Algılanan Hizmet Kalitesi, Memnuniyet ve Davranışsal Niyetler Arasındaki İlişkilerin İncelenmesi: Edremit Örneği, Anatolia: Turizm Araştırmaları Dergisi, 27(2): 181-194.

Jackson, S. A., Martin, A. J. and Eklund, R. C. (2008). Long and Short Measures of Flow: The Construct Validity of the FSS-2, DFS-2 and New Brief Counterparts, Journal of Sport and Exercise Psychology, 30: 561-587.

Karaca, K. Ç. (2018). Restoran Atmosferinin Tekrar Ziyaret Niyetine Etkisi: Akış Deneyiminin Aracılık Rolü, Yayımlanmamış Yüksek Lisans Tezi, Balıkesir Üniversitesi, Balıkesir.

Kim, M. and Thapa, B. (2018). Perceived Value and Flow Experience: Application in a Naturebased Tourism Context, Journal of Destination Marketing \& Management, 8: 373-384. 
Köroğlu, A., Köroğlu, Ö., Şalk, S. ve Dumanll, Ş. (2018). Turist Rehberlerinin Yorumlayıcı Rollerine Yönelik Algılarının Betimsel Analiz Yöntemiyle Belirlenmesi, (Editör) Hacıŏ̆lu, N., Avcıkurt, C., Kılıç, A. ve Yıldırım, H. U.: Turist Rehberliği Üzerine Güncel Araştırmalar içinde (ss. 342-359) Ankara: Detay Yayıncilik.

Lee, J., Graefe, A. R. and Burns, R. C. (2004). Service Quality, Satisfaction and Behavioral Intention Among Forest Visitors, Journal of Travel and Tourism Marketing, 17(1): 73-82.

Liu, C. R., Lin, W. R. and Wang, Y. C. (2012). Relationship Between Self-congruity and Destination Loyalty: Differences Between First-time and Repeat Visitors, Journal of Destination Marketing $\mathcal{E}$ Management, 1(1-2): 118-123.

Moscardo, G. (2003). Interpretation and Sustainable Tourism: Functions, Examples and Principles, The Journal of Tourism Studies, 14(1): 112-123.

Parasuraman, A. and Grewal, D. (2000). The Impact of Technology on the Quality-Value-Loyalty Chain: A Research Agenda, Journal of the Academy of Marketing Science, 28(1): 168-74.

Seligman, M. E. P., Steen, T., Park, N. and Peterson, C. (2005). Positive Psychology Progress: Empirical Validation of Interventions, America Psychologist, 60: 410421.

Sheth, J. N., Newman, B. I. and Gross, L. G. (1991). Why We Buy What We Buy: A Theory of Consumption Values, Journal of Business Research, 22: 159-170.

Sweeney, J. C. and Soutar, G. N. (2001). Consumer Perceived Value: The Development of a Multiple Item Scale, Journal of Retailing, 77: 203-220.

Tangpattanakit, J. (2017). The Moderating Effect of Social Media Involvement and Brand Love on the Consumer Perceived Values and Purchasing Intention of Fast-fashion Products, Yayımlanmamış Doktora Tezi, Brunel Üniversitesi, İngiltere.

Usullu, Ö. (2019). Turist Rehberlerine Yönelik Algılanan Hizmet Kalitesinin Davranışsal Niyetlere Etkisi: Çanakkale Örneği, Yayımlanmamış Yüksek Lisans Tezi, Çanakkale Onsekiz Mart Üniversitesi, Çanakkale.

Yenipınar, U. (2019). Turist Rehberliği Mesleği, (Editör) Güzel, Ö. ve Köroğlu, Ö.: Kavramdan Uygulamaya Turist Rehberliği Mesleği içinde (ss. 1-18) Ankara: Nobel Akademik Yayıncılık.

Yeşiltaş, M. D. ve Ekici, E. (2017). İş Akış Deneyiminin Kişilik Özellikleri ve İş Stresi ile İlişkisi: Akademik Personel Üzerine Bir Araştırma, Çukurova Üniversitesi Sosyal Bilimler Enstitüsü Dergisi, 26(1): 1-11.

Yoon, Y. and Uysal, M. (2005). An Examination of the Effects of Motivation and Satisfaction on Destination Loyalty: A Structural Model, Tourism Management, 26(1): 45-56.

Zeithaml, V. A. (1988). Consumer Perception of Price, Quality, and Value: A Means-end Model and Synthesis of Evidence, Journal of Marketing, 52(3): 2-22.

Zeithaml, V. A., Berry, L. L. and Parasuraman, A. (1996). The Behavioral Consequences of Service Quality, Journal of Marketing, 60(2): 31-46.

Williams, P. and Soutar, G. (2000). Dimensions of Customer Value and the Tourism Experience: An Exploratory Study. Global Conference on Australian and New Zealand Marketing Academy Conference (ANZMAC), 28 November-1 December, Australia. 